\title{
Structural Pounding between Adjacent Buildngs during Earthquakes
}

\author{
K Dada Hayath ${ }^{1}$ | Dr.C.Raja Ram ${ }^{2}$ \\ ${ }^{1}$ Department of Civil Engineeering, Anantha Lakshmi Institute of Technology and Sciences, Anantapur Dist, Andhra \\ Pradesh, India \\ ${ }^{2}$ Department of Civil Engineering, RGM College of Engineering and Technology, Kurnool Dist, Andhra Pradesh, India
}

To Cite this Article

K Dada Hayath and Dr.C.Raja Ram, "Structural Pounding between Adjacent Buildngs during Earthquakes", International Journal for Modern Trends in Science and Technology, Vol. 07, Issue 03, March 2021, pp.: 142-150.

\section{Article Info}

Received on 03-February-2021, Revised on 02-March-2021, Accepted on 05-March-2021, Published on 14-March-2021.

\section{ABSTRACT}

In India multi-storied buildings are usually constructed, due to high cost and scarcity of land inhabitant places. In order to utilize maximum land area, buildings are constructed generally asymmetrical plan and adjacent to each other. The reports after major earthquakes indicate that the earthquake induced pounding between insufficiently separated buildings may lead to significant damage or even total collapse of structure. This paper examines the collision between adjacent reinforced concrete (RC) buildings under earth-quakes. In this study, two buildings with equal heights, unequal heights are analyzed. To understand torsional behaviour of buildings due to pounding, torsional pounding effect is also considered. To per-form the above cases, the buildings are modeled in standard structural software (SAP2000). For the purpose of study, time history analysis is used. The results are shown in terms of pounding responses, acceleration response and pounding forces.

KEYWORDS: Multi-storied buildings, Pounding behavior,SAP2000, Time history analysis.

\section{INTRODUCTION}

\section{What is an earthquake?}

An earthquake is what happens when two blocks of the earth suddenly slip past one another. The surface where they slip is called the fault or fault plane. The location below the earth's surface where the earthquake starts is called the hypocenter, and the location directly above it on the surface of the earth is called the epicenter.

\section{Pounding}

Structural seismic pounding refers to collision between adjacent structures during earthquakes. It is induced when the structures with different dynamic characteristics, having insufficient separation vibrate out of phase.
The seismic pounding of structures is studied through numerical simulations, focusing on multi-storey reinforced concrete (RC) buildings.

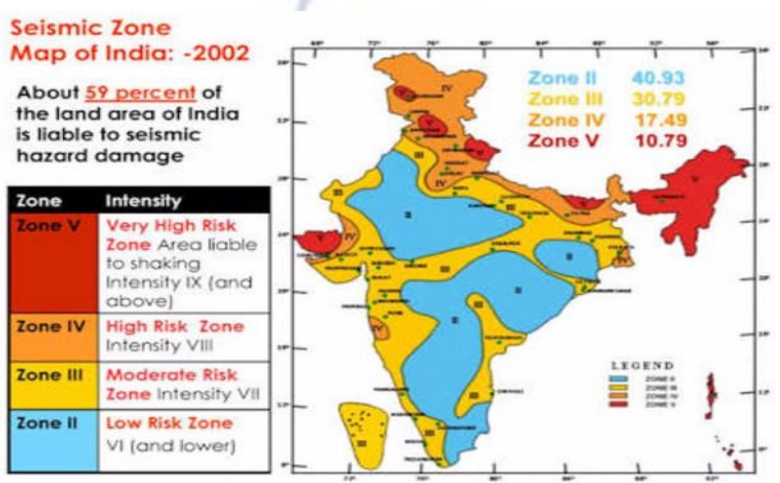

Fig 1:Various Earthquake zones in India 


\section{Pounding Effects}

When two buildings are located very close to each other or when seismic expansion joints exist, pounding is occurred. So, it is necessary to provide enough space between neighboring structures so that they do not pound each other. Extra distance is provided between two adjacent buildings in addition to the sway of the buildings in computing lateral displacement, it is necessary to consider plastic deflection, soil-structure interaction and other factors besides elastic deflection. The pounding effect can be easily seen in highly populated cities. This effect can be controlled by placing elastic materials between adjacent buildings or by reinforcing structural systems with cast-in-place reinforced concrete $(\mathrm{RC})$ walls. As per IS 1893:2002, two adjacent buildings. or two adjacent units of the same building with separation joint in between shall be separated by a distance equal to the amount $\mathrm{R}$ times the sum of the calculated storey displacements, to avoid damaging contacts when the two units deflect towards each other.

Although earthquake loading is commonly considered in structural design, pounding of adjacent buildings is not usually considered and usually causes highly unexpected damages and failures. Pounding effect was numerically investigated in this study, where adjacent buildings were designed to resist lateral earthquake loads without taking into consideration the additional applied force resulting from pounding. Nonlinear dynamic analysis was carried using the Applied Element Method (AEM). Pounding of buildings of different structural systems, different gravity loading and different floor heights was investigated. Dynamic behavior in terms of additional base shear, base bend- ing moments and pounding forces was investigated for different gap distances less than the safe gap distance specified by the Egyptian Code of Practice (ECP). Effect of gap distance, building's dynamic characteristics, building's height and gravity loads on additional straining actions due to impact was discussed.

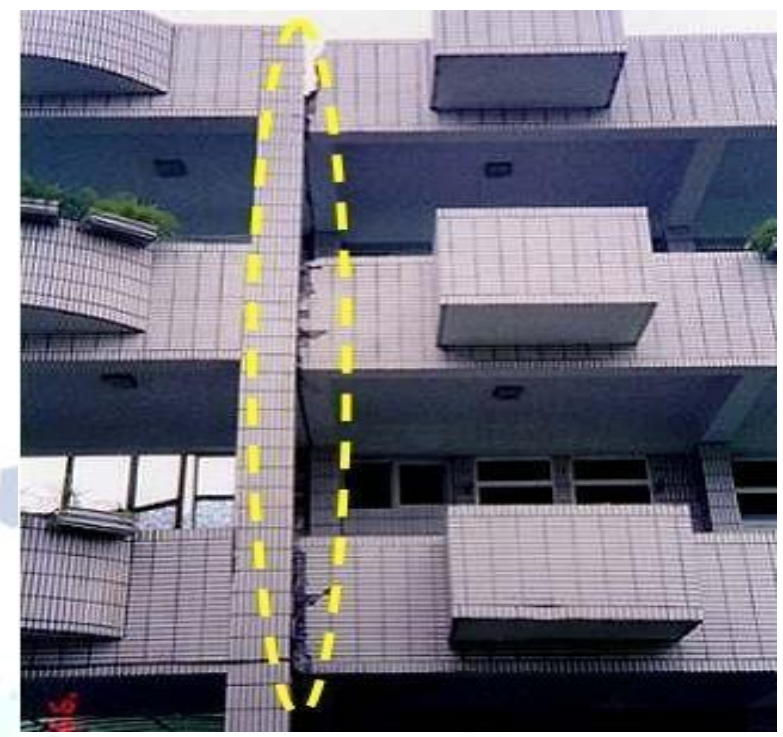

Fig 2: Pounding damage due to insufficient separation distance during 1999 Chi-Chi earthquake, Taiwan

\section{Indian observations}

The observations on pounding from the Indian earthquakes are as follows: The powerful 2001 Bhuj earthquake (Jain et al., 2001) has been the most damaging earthquake in the last five decades in India. Pounding of adjacent structures was evident at Ayodhya apartments in Ahmedabad with significant damages. The Sikkim earth- quake (Kaushik et al., 2006) on 14th February 2006 of 5.3 magnitude caused damage to a nine storey masonry infill RC frame hostel building at Sikkim Manipal Institute of Medical Sciences (SMIMS) Tadong, Gangtok which caused severe damages in walls and columns. Pounding damages were observed between two long wings in the building and corridors connecting the wings.

From above observations, it is concluded that major pounding damages are caused due to insufficient separation distance. Hence, there is a need to do research on separation distance between adjacent structures and pounding behavior of structures during earthquakes.

\section{MODELLING OF BUIDLING}

Geometric Details

In these geometric details, the details of plan and elevation are described. The plan is drawn as per BIS standards. The length, breadth and height of building are $12.35 \mathrm{~m}, 14.45 \mathrm{~m}$ and $13.72 \mathrm{~m}$ respectively. 


\begin{tabular}{|l|c|c|}
\hline \multicolumn{1}{|c|}{ Rooms } & $\begin{array}{c}\text { Min } \\
\text { Dimensio } \\
\text { ns }\end{array}$ & $\begin{array}{c}\text { Provided } \\
\text { Dimension } \\
\text { s }\end{array}$ \\
\hline Living room & $9.5 \mathrm{~m} 2$ & $29.016 \mathrm{~m} 2$ \\
\hline Bed room & $9.5 \mathrm{~m} 2$ & $14.4 \mathrm{~m} 2$ \\
\hline Kitchen & $5.0 \mathrm{~m} 2$ & $12.96 \mathrm{~m} 2$ \\
\hline $\begin{array}{l}\text { Combined } \\
\text { bath room } \\
\text { Water closet }\end{array}$ & $2.8 \mathrm{~m} 2$ & $3.24 \mathrm{~m} 2$ \\
\hline Dining room & $9.5 \mathrm{~m} 2$ & $12.96 \mathrm{~m} 2$ \\
\hline $\begin{array}{l}\text { Stair case } \\
\text { Trend }\end{array}$ & $0.8 \mathrm{~m}$ & $0.9 \mathrm{~m}$ \\
\hline Rise & $0.2 \mathrm{~m}$ & $0.2 \mathrm{~m}$ \\
\hline
\end{tabular}

Table 1: NBC Standard dimensions

\begin{tabular}{|c|c|c|c|c|}
\hline roup & $\begin{array}{l}\text { Grade } \\
\text { designat } \\
\text { ion }\end{array}$ & $\begin{array}{l}\text { Specifie } \\
\text { d } \\
\text { charact } \\
\text { eristic } \\
\text { compre } \\
\text { ssive } \\
\text { strengt } \\
\text { h } \\
\left(\mathrm{N} / \mathrm{mm}^{2}\right)\end{array}$ & $\begin{array}{l}\text { Density } \\
\left(k N / m^{3}\right)\end{array}$ & $\begin{array}{l}\text { Tensil } \\
\text { e } \\
\text { streng } \\
\text { th } \\
(\mathrm{kN} / \mathrm{m} \\
\text { 3) }\end{array}$ \\
\hline $\begin{array}{l}\text { Standa } \\
\text { rd } \\
\text { Concre } \\
\text { te }\end{array}$ & M25 & 25 & 25 & \\
\hline Steel & $\mathrm{Fe} 415$ & - & 78.5 & $\begin{array}{c}41 \\
5\end{array}$ \\
\hline
\end{tabular}

Table 2: Material properties: as per IS: $456-2000$

\section{Load Case Details}

The loads such as live load, imposed load, floor finish load are taken as per IS: 875-1987 (part 2). Dead loads are calculated based on the properties of materials used for building.

- Live load $=3 \mathrm{kN} / \mathrm{m}^{2}$

-Imposed load $=0.3 \mathrm{kN} / \mathrm{m}^{2}$

- Floor finish load $=1.5 \mathrm{kN} / \mathrm{m}^{2}$

- Roof live load $=1.5 \mathrm{kN} / \mathrm{m}^{2}$

- Wall load $=8.694 \mathrm{kN} / \mathrm{m}^{2}$

- Partition load $=2.0 \mathrm{kN} / \mathrm{m}^{2}$

- Parapet load $=4.6 \mathrm{kN} / \mathrm{m}^{2}$

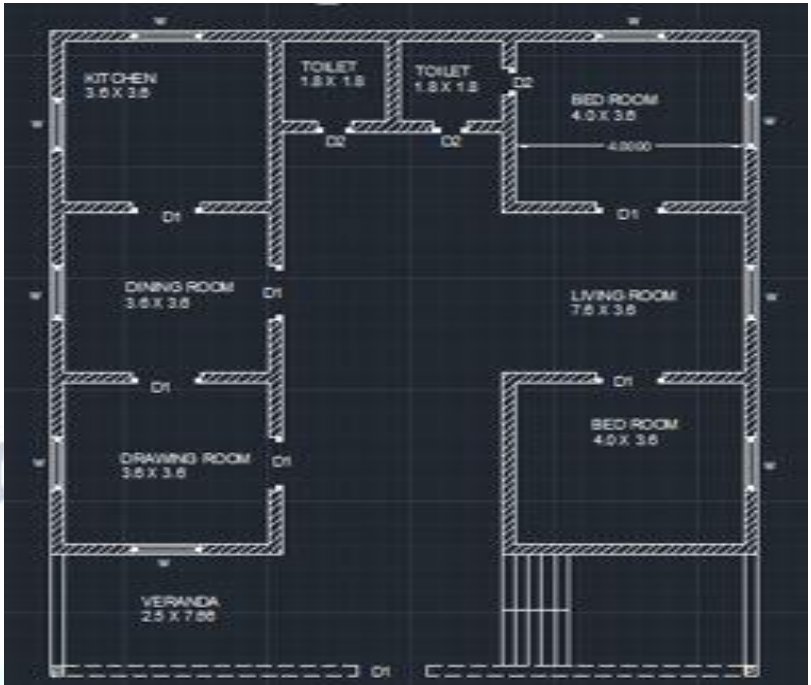

Figure 3.1: Plan of the building (all the dimensions are in $\mathrm{m}$ )

\section{Gap Element Model}

Gap joint element is an element which connects two adjacent nodes to model the contact. This is activated when structures come closer and deactivate when they go far away. A collision force will be generated when they come closer. Gap joint element is an element which connects two adjacent nodes to model the contact. This is activated when structures come closer and deactivate when they go far away. A collision force will be generated when they come closer. which nonlinear properties were specified. For all other degrees of freedom, the linear effective stiffnesses are used during a nonlinear analysis. The results for linear analyses are based upon linear effective stiffness and damping properties. Only the results for nonlinear analysis cases include the nonlinear behavior. The force-deformation relationship is as follows:

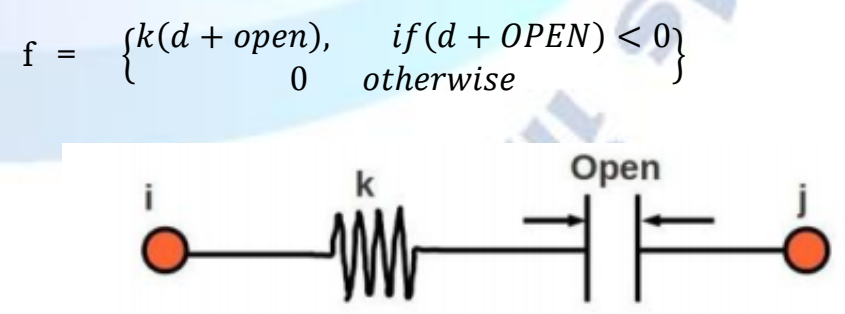

Figure:3: Gap Joint element for SAP 2000

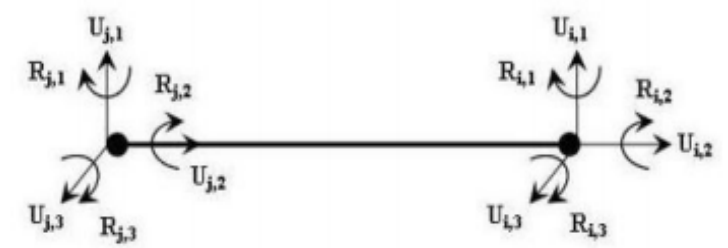

Figure 4: Link Element internal forces and moments and joints 
Where, $\mathrm{k}$ is spring constant, open is the gap opening which must be positive or zero and $d$ is the relative deformation across the spring.

\section{LATERAL LOAD ANALYSIS}

\section{Equivalent Static Analysis}

In Equivalent Static Analysis the seismic load shall be assumed as an equivalent static horizontal force applied to individual frames .The total applied force shall be equal to the product of acceleration response spectrum (ARS) and the tributary weight .The horizontal force shall be applied at the vertical centre of mass of the superstructure and distributed horizontally in proportion to the distribution. Equivalent Static force method is an empirical formula dependent on height of structure and also evaluates the height wise distribution of storey force. The lateral force in terms of the base shear and the static analysis of the structure for these forces provide the base shears.

\section{Design spectrum (Ah)}

$\mathrm{V}_{\mathrm{b}}=\mathrm{A}_{\mathrm{h}} \mathrm{xw}$ (As per ISI 1893, part 1 clause 7.5.3) Where

$\mathrm{Ah}=$ Design spectrum

$\mathrm{W}=$ seismic weight of the building

$\mathrm{Z}=$ zone factor

$\mathrm{I}=$ important factor

$\mathrm{R}=$ Response reduction factor

$\mathrm{Sa} / \mathrm{g}=$ Average response acceleration coefficient

\section{Calculation of seismic weight (W)}

$\mathrm{W}=$ Dead load $+25 \%$ live load

Total height of building: $13.72 \mathrm{~m}$

Total breadth of building: $14.45 \mathrm{~m}$

Total width of building: $12.35 \mathrm{~m}$

Dead load calculation

Self-weight of slabs $=14.45 \times 12.35 \times 0.13 \times 25$ $=579.98 \mathrm{KN}$

Self-weight of beams $=0.23 \times 0.3 \times 25 \times 115.41=$ $199.08 \mathrm{KN}$

Self-weight of columns $=135 \mathrm{kN}$

Self-weight of walls $=1222.68 \mathrm{kN}$

Dead load on each floor

=self-weight $($ slab +beams +column +walls $)=$ $2136.76 \mathrm{kN}$

Total Dead load of building $=8546.96 \mathrm{kN}$
Live load on floors $==133.84 \mathrm{kN}$

Seismic weight on floor $=$

Dead load + live load $=2270.6 \mathrm{kN}$

Total seismic weight of structure $\mathrm{w}=4 \mathrm{x}$ floor load $=4 \times 2270.6=9082.4 \mathrm{kN}$

In x-direction

$\mathrm{A}_{\mathrm{h}}=\frac{Z I S a}{2 R g}=\frac{0.11}{25} 2.5=0.025$

$\mathrm{Ta}=\frac{0.09 h}{\sqrt{d}}=0.351 \mathrm{sec}$

In Y-direction

$\mathrm{A}_{\mathrm{h}}=\frac{Z I S a}{2 R g}=\frac{0.11}{25} 2.5=0.025$

$\mathrm{Ta}=\frac{0.09 h}{\sqrt{d}}=0.32 \mathrm{sec}$

\section{Design Shear base $\mathbf{V}_{b}$}

Design Shear base $\mathrm{V}_{\mathrm{bx}}(\mathrm{In} \mathrm{X}$-direction)

$=\mathrm{A}_{\mathrm{h}}{ }^{*} \mathrm{~W}=227.05 \mathrm{KN}$

Design Shear base $\mathrm{V}_{\text {by }}(\mathrm{In} \mathrm{Y}$-direction)

$=\mathrm{A}_{\mathrm{h}}{ }^{*} \mathrm{~W}=227.05 \mathrm{KN}$

Design base shear shall be distributed along the height of building using the following equation

$\mathrm{Q}_{\mathrm{i}}=\mathrm{V}_{\mathrm{b}} \frac{\left(W i x h i^{2}\right)}{\left(\sum_{i=1}^{n} W i x h i^{2}\right)}$

Where

$\mathrm{Q}_{\mathrm{i}}=$ design lateral force at floor $\mathrm{i}$

$\mathrm{W}_{\mathrm{i}}=$ seismic weight of floor $\mathrm{i}$

$\mathrm{h}_{\mathrm{i}}=$ height of floor I measured from base

$\mathrm{n}=$ number of storeys in the building

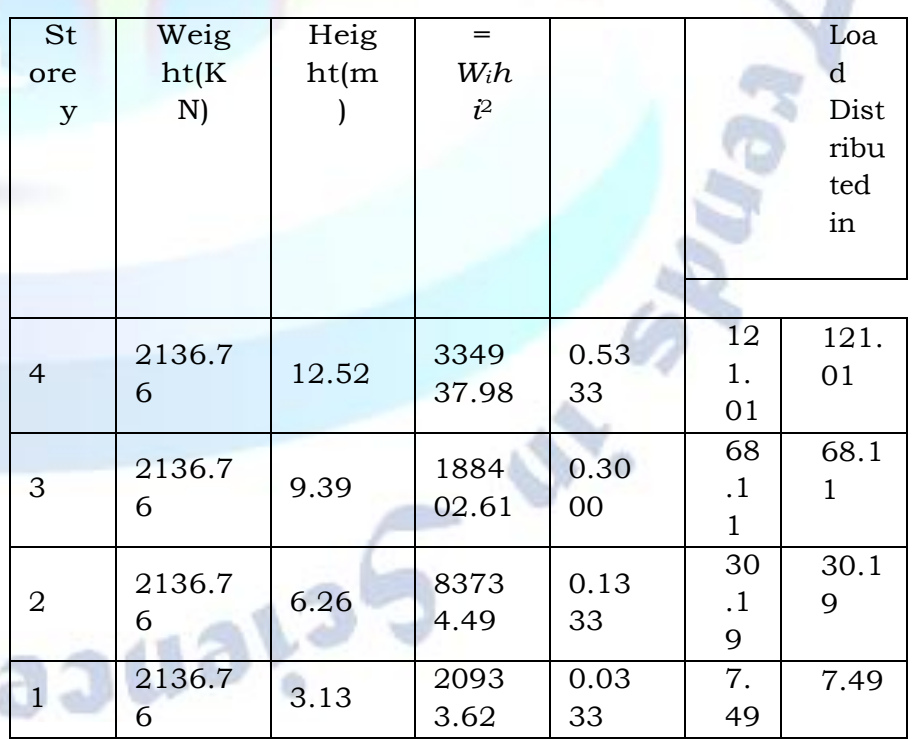

Table 3 : Horizontal load on each storey

\section{Dynamic Analysis}

The seismic response of a building depends on its dynamic characteristics (fundamental period and mode shapes) and on the input ground motion.

\section{Live Load Calculation}




\section{Ground motion}

Ground motion is produced by waves that are generated by sudden slip on a fault or sudden pressure at the explosive source and travel through the earth and along its surface In this study, the buildings are subjected to various ground motions (the Nepal earthquake (2015) accelerograms) to understand the pounding behaviour of buildings.

\begin{tabular}{|r|r|r|}
\hline $\begin{array}{l}\text { Station } \\
\text { name }\end{array}$ & $\begin{array}{l}\text { pre- ground } \\
\text { acceleration } \\
(\mathrm{cm} / \mathrm{sec})\end{array}$ & $\begin{array}{c}\text { frequency(time) } \\
\text { (sec) }\end{array}$ \\
\hline KTP & 254.785 & $0.24-0.38$ \\
\hline PTN & 150.683 & $3.85-4.54$ \\
\hline THM & 149.303 & $3.85-4.54$ \\
\hline TVU & 228.753 & $1.28-3.84$ \\
\hline
\end{tabular}

Table 4: Characteristics of Ground motions

\section{Dynamic charecteristics of Building}

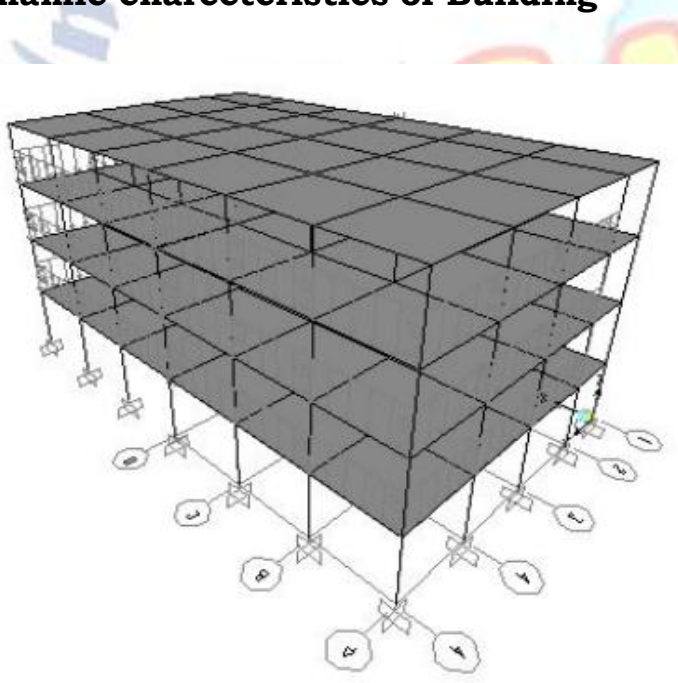

Figure 5: 3D View of Building

\begin{tabular}{|l|l|l|l|}
\hline $\begin{array}{l}\text { Type of } \\
\text { Building }\end{array}$ & $\begin{array}{l}\text { Time period } \\
\text { In } \\
\text { X-direction } \\
(\mathrm{sec})\end{array}$ & $\begin{array}{l}\text { Time period } \\
\text { in } \\
\text { Y direction } \\
(\mathrm{sec})\end{array}$ & $\begin{array}{l}\text { Time } \\
\text { period } \\
\text { In } \\
\text { Zdirectio } \\
\mathrm{n}(\mathrm{sec})\end{array}$ \\
\hline $\begin{array}{l}\text { Left side } \\
\text { building }\end{array}$ & 0.40582 & 0.39241 & 0.34327 \\
\hline $\begin{array}{l}\text { Right } \\
\text { building }\end{array}$ & 0.22111 & 0.21198 & 0.19086 \\
\hline
\end{tabular}

Table 5: Time Period of Buildings

\section{RESULTS}

\section{Response at Different joints}

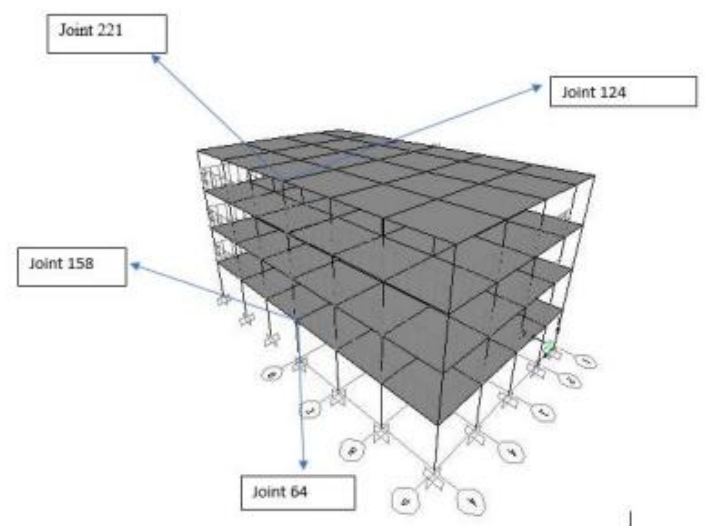

Figure 6: Response at different links in Building

\section{Displacement and Accelaration Responses}

\section{KTPR.HNE}

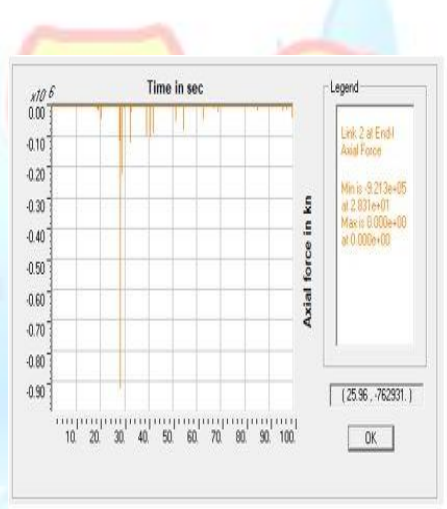

a)Axial force at link2

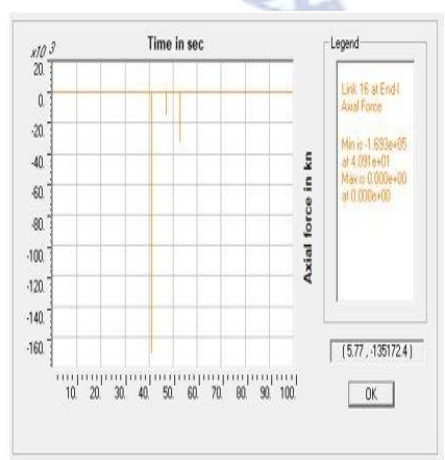

b)Axial force at link16
Figure 9: Axial forces for KTPR.HNE ground motion at different links

\section{KTPR.HNN}
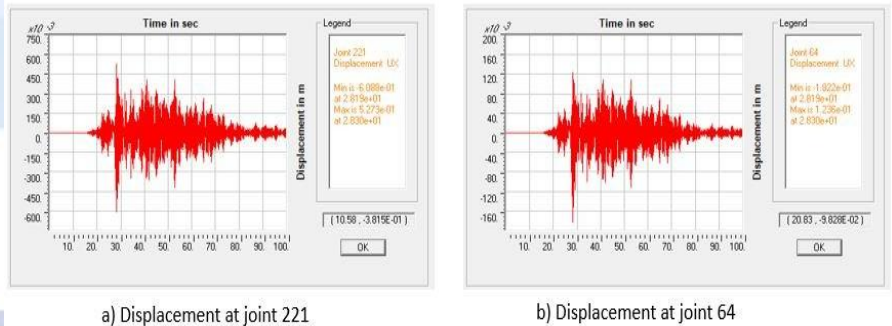

b) Displacement at joint 64
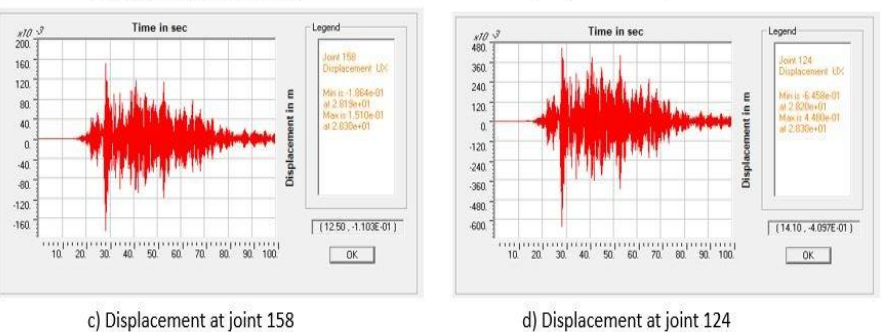

d) Displacement at joint 124

Figure 10- Displacement Responses for KTPR.HNN ground motion at different joints 


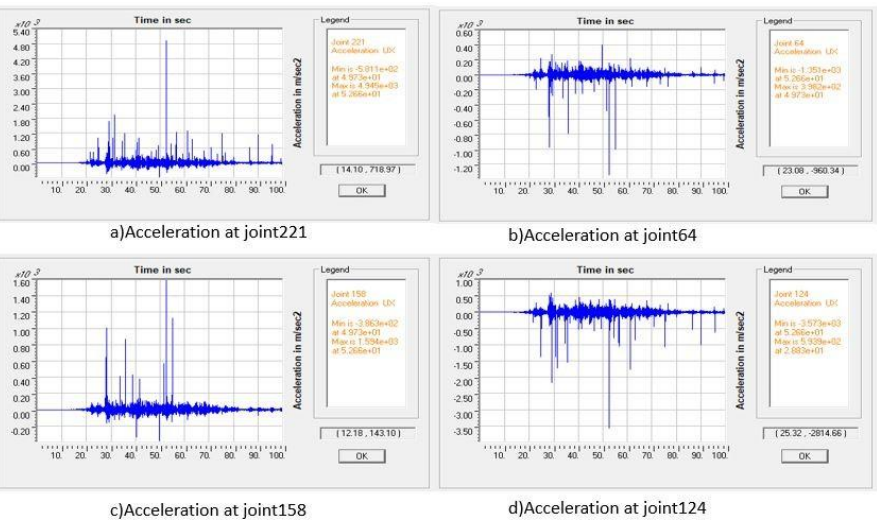

Figure 11 - Acceleration Responses for KTPR.HNN ground motion at different joints

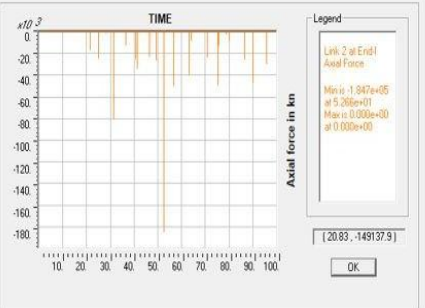

a)Axial force at link2

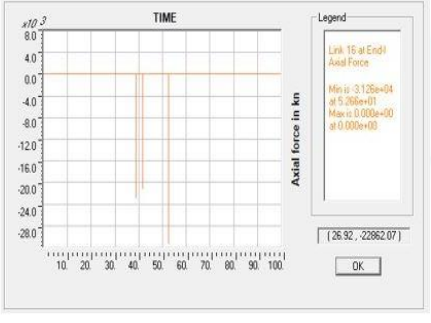

b)Axial force at link16
Figure 12- Axial forces for KTPR.HNN ground motion at different links

\section{PTNR.HNE}
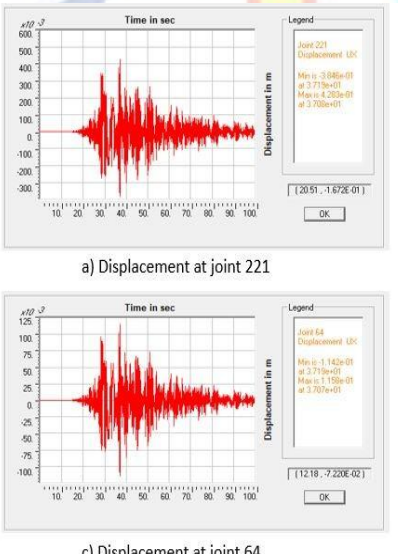

c) Displacement at joint 64

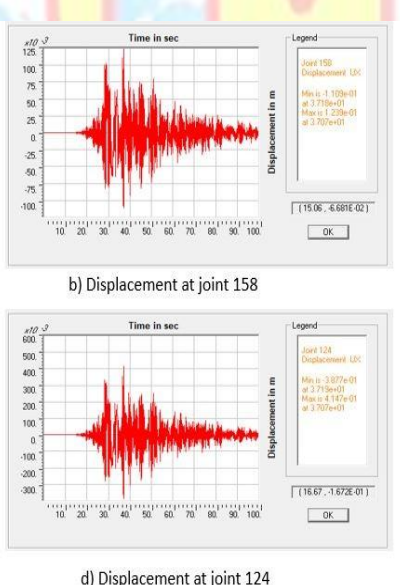

Figure 13- Displacement Responses for PTNR.HNE ground motion at different joints
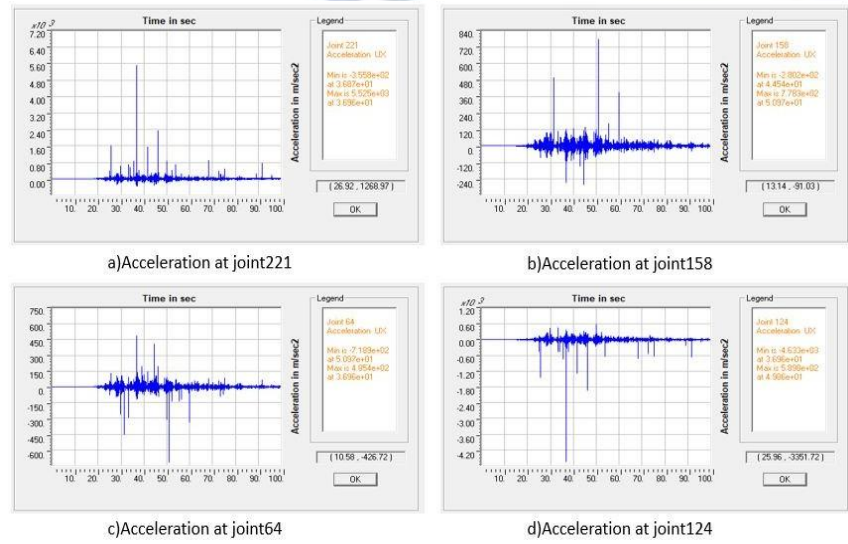

Figure 14- Acceleration Responses for PTNR.HNE ground motion at different joints

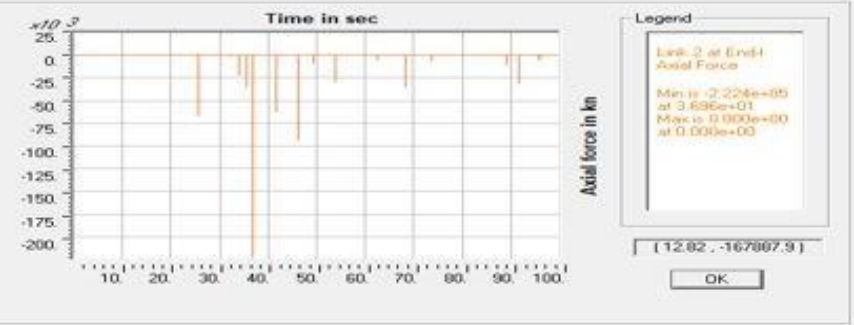

a)Axial force at link2

Figure 15: Axial forces for PTNR.HNE ground motion at different links

\section{PTNR.HNN}
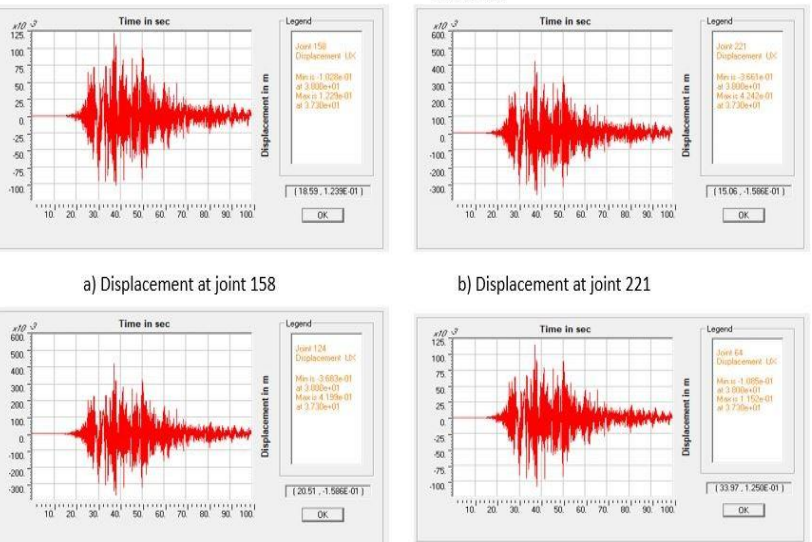

b) Displacement at joint 221

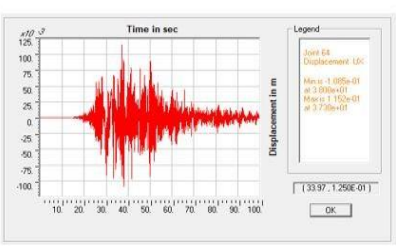

c) Displacement at joint 124

d) Displacement at joint 64

Figure 16- Displacement Responses for PTNR.HNN ground motion at different joints
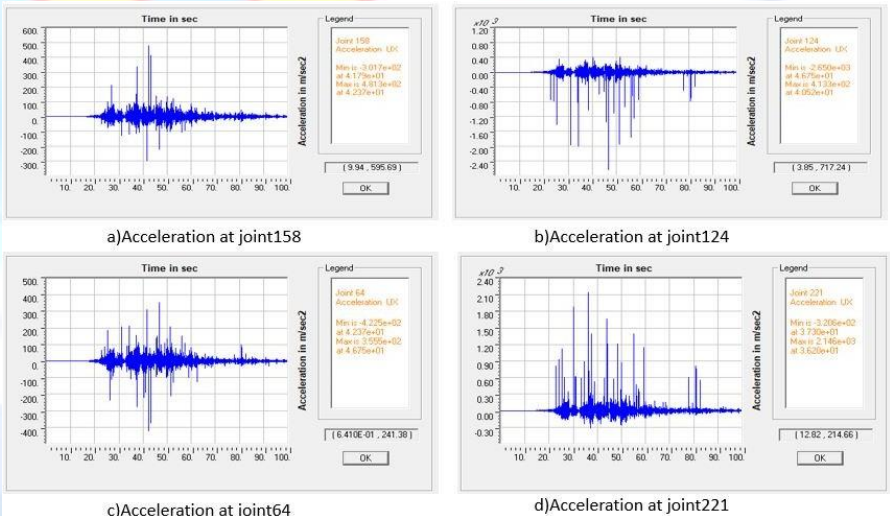

c)Acceleration at joint 64

Figure 17-Acceleration Responses for PTNR.HNN ground motion at different joints

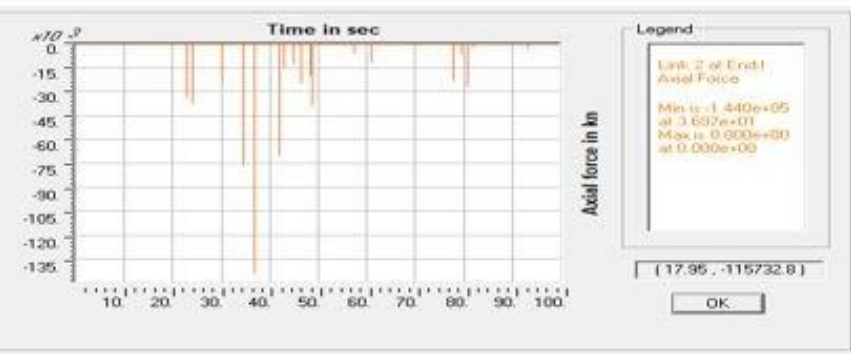

a)Axial force at link2

Figure 18: Axial forces for PTNR.HNN ground motion at different links. 


\section{THMR.HNE}

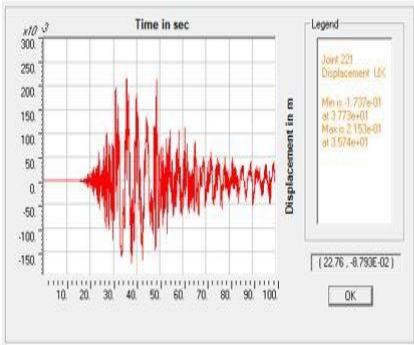

a) Displacement at joint 221

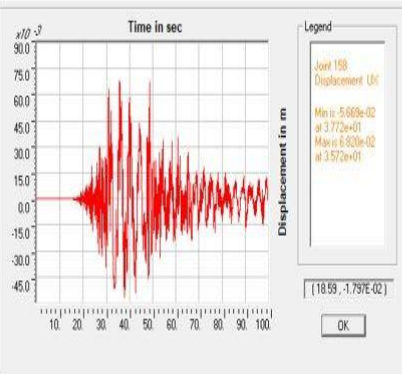

c) Displacement at joint 158

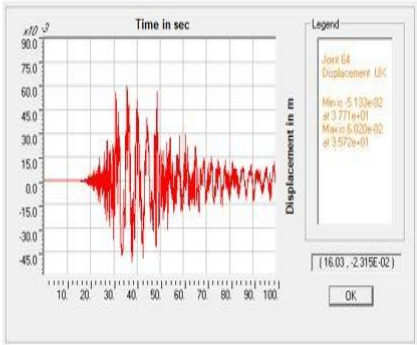

b) Displacement at joint 64

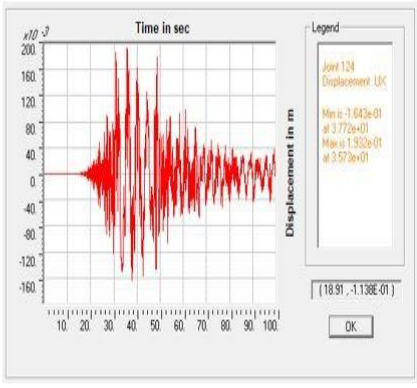

d) Displacement at joint 124

Figure 19: Displacement Responses for THMR.HNE ground motion at different joints
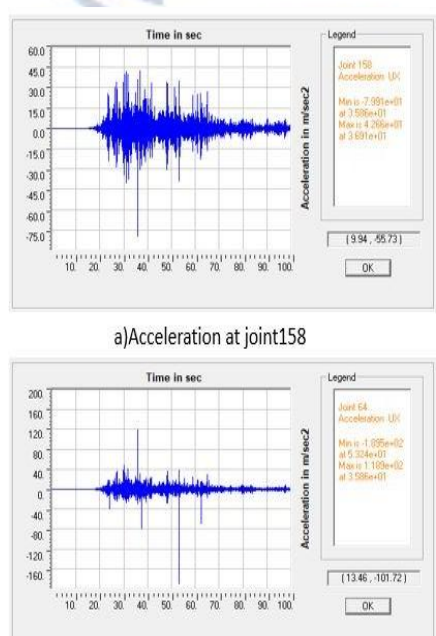

c)Acceleration at joint64
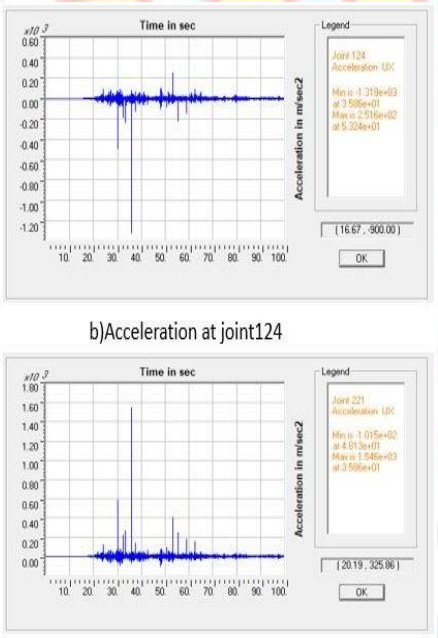

d)Acceleration at joint221

Figure 20: Acceleration Responses for THMR.HNE ground motion at different joints

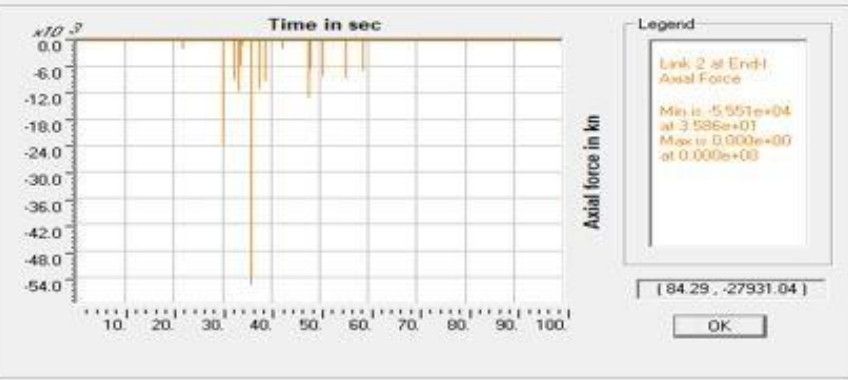

a)Axial force at link2

Figure 21: Axial forces for TMR.HNE ground motion at different links

\section{THMR.HNN}
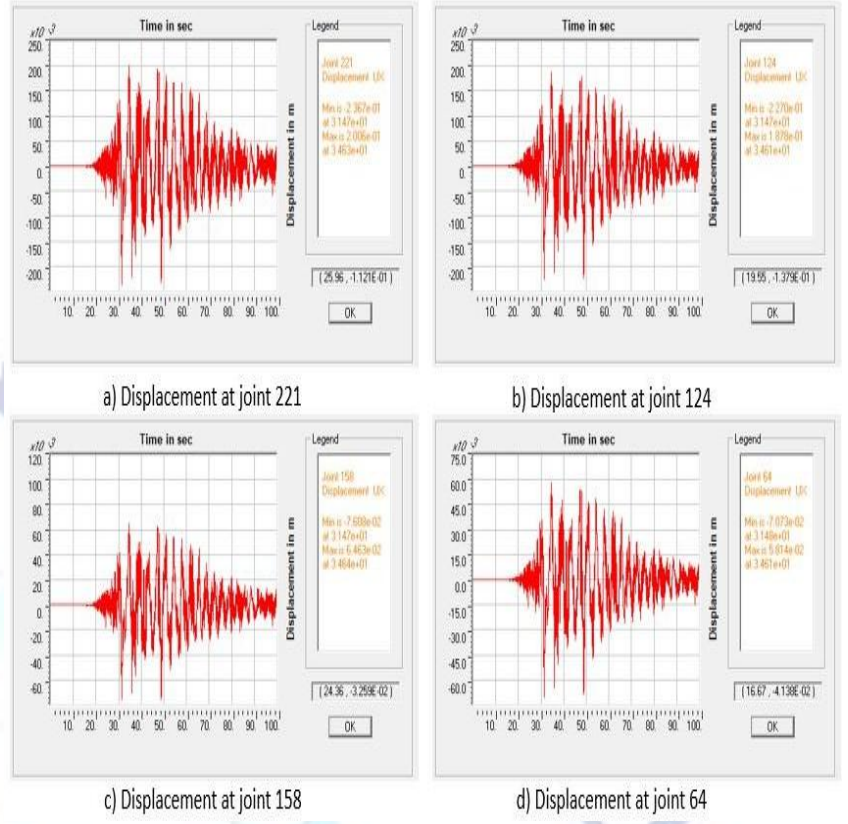

Figure 22: Displacement Responses for THMR.HNN ground motion at different joints
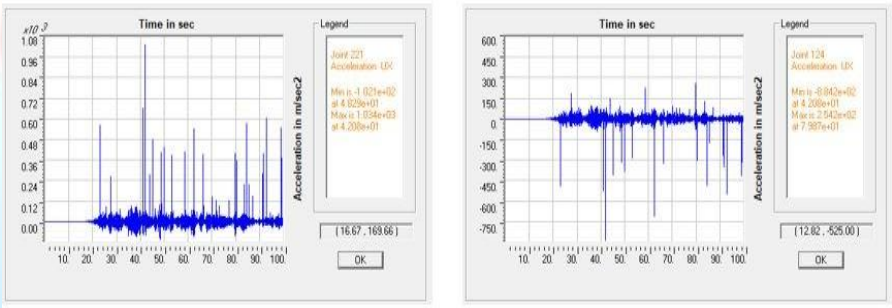

d)Acceleration at joint221

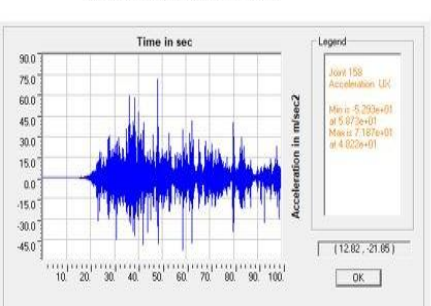

c)Acceleration at joint158

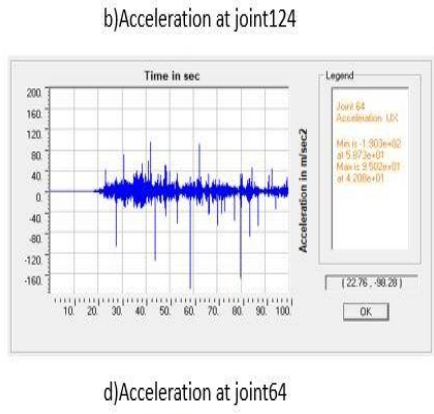

Figure 23: Acceleration Responses for THMR.HNN ground motion at different joints

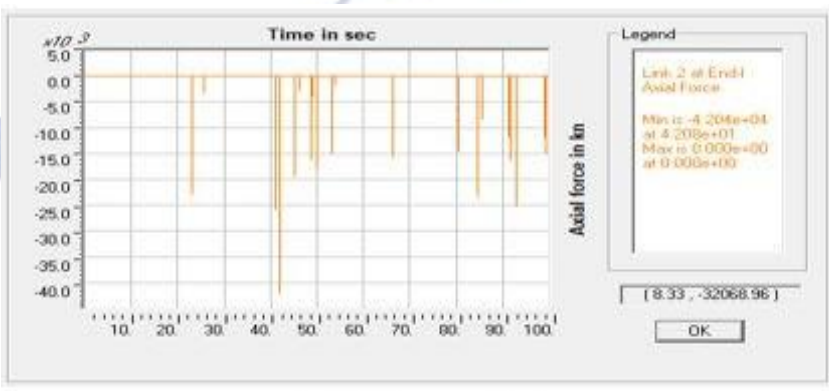

a)Axial force at link2

Figure 21: Axial forces for TMR.HNN ground motion at different links 


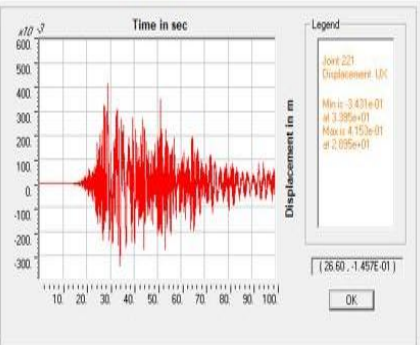

a) Displacement at joint 221

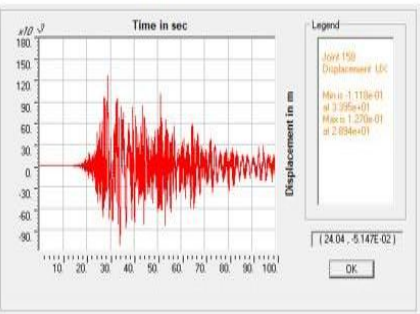

c) Displacement at joint 158

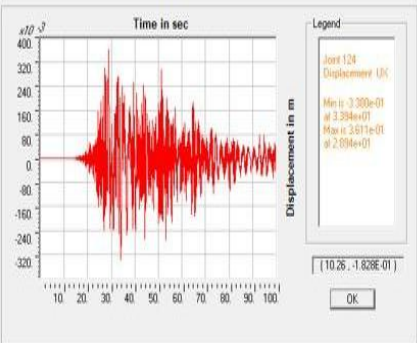

b) Displacement at joint 124

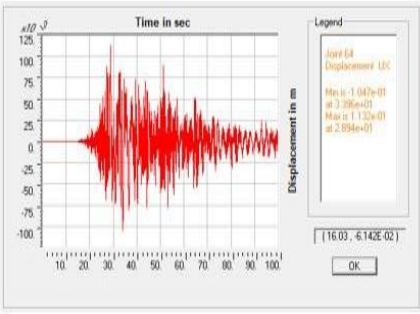

d) Displacement at joint 64

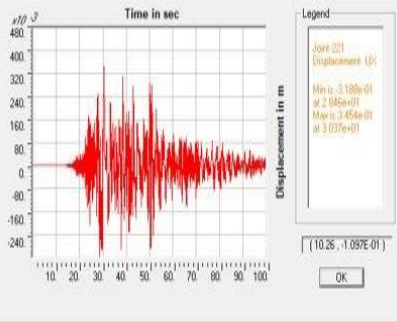

a) Displacement at joint 221

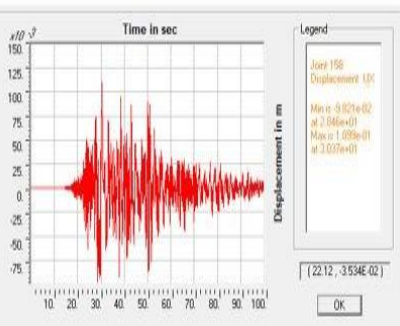

c) Displacement at joint 158

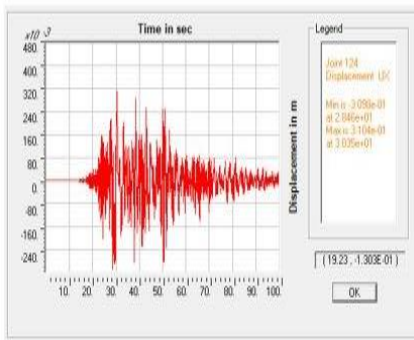

b) Displacement at joint 124

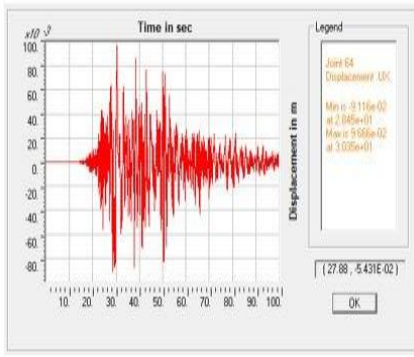

d) Displacement at joint 64
Figure 22: Displacement Responses for TUVR.HNE ground motion at different joints

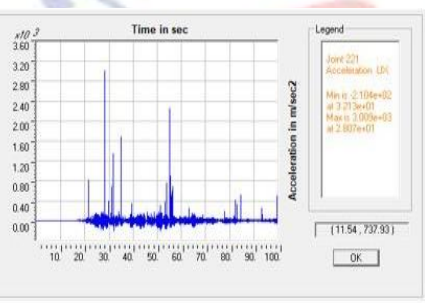

a)Acceleration at joint221

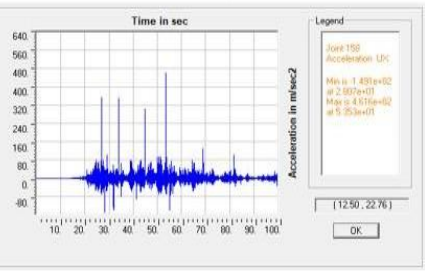

c)Acceleration at joint158

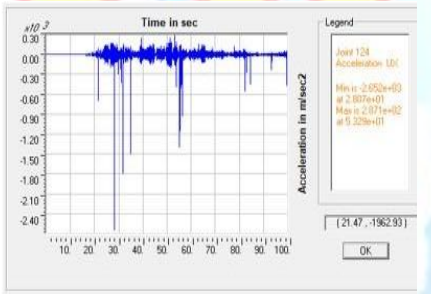

b)Acceleration at joint124

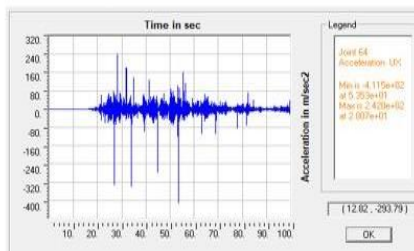

d)Acceleration at joint64

Figure 23: Accelaration Responses for TUVR.HNE ground motion at different joints

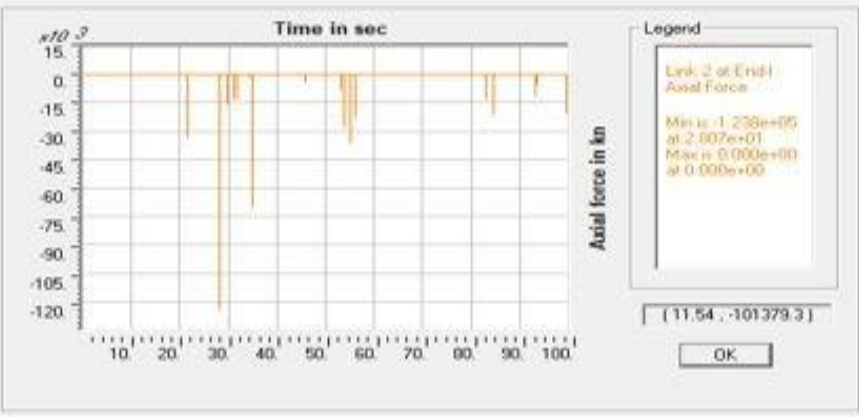

a)Axial force at link2

Figure 24: Axial forces for TVUR.HNE ground motion at different links

Figure 25: Displacement Responses for TUVR.HNN ground motion at different joints
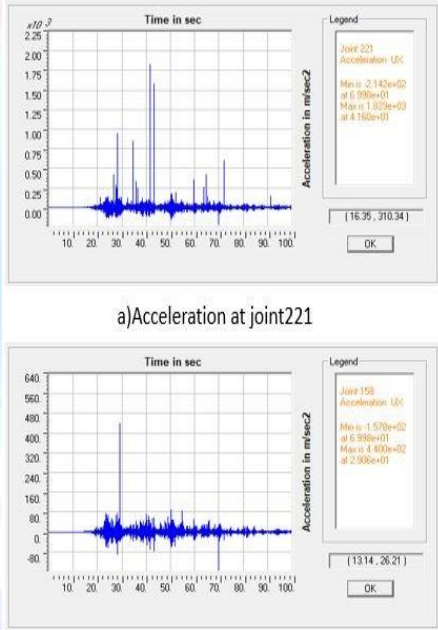

c) Acceleration at joint 158

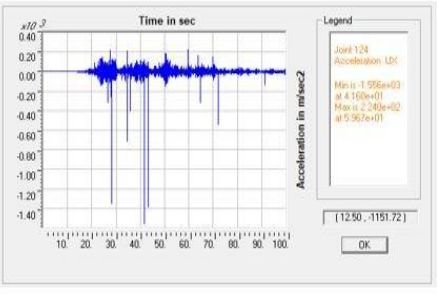

b)Acceleration at joint124

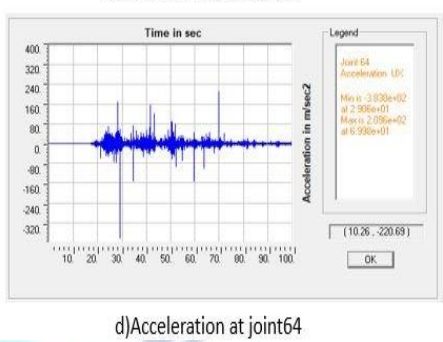

Figure 26: Accelaration Responses for TUVR.HNN ground motion at different joints

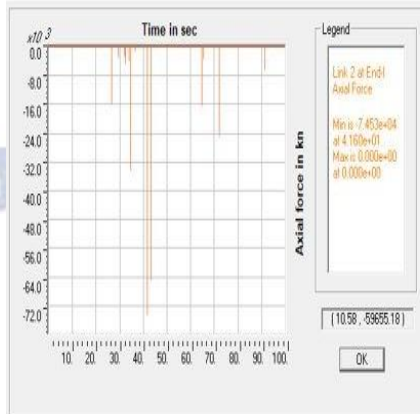

a)Axial force at link2

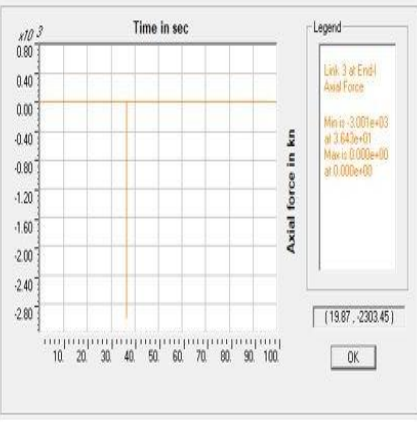

B)Axial force at link3
Figure 27: Axial forces for TVUR.HNN ground motion at different links 


\begin{tabular}{|c|c|c|c|c|}
\hline \multicolumn{5}{|c|}{ Displacement in m } \\
\hline $\begin{array}{c}\text { joint } \\
\text { no }\end{array}$ & $\begin{array}{c}\text { KTPR } \\
\text {.HNN }\end{array}$ & $\begin{array}{c}\text { KTPR. } \\
\text { HNE }\end{array}$ & $\begin{array}{c}\text { PTNR. } \\
\text { HNN }\end{array}$ & $\begin{array}{c}\text { PTNR } \\
\text {.HNE }\end{array}$ \\
\hline $\mathbf{2 2 1}$ & 0.5273 & 1.27 & 0.4258 & 0.4297 \\
\hline $\mathbf{1 2 4}$ & 0.448 & 1.89 & 0.4202 & 0.41 \\
\hline $\mathbf{1 5 8}$ & 0.151 & 0.3743 & 0.1242 & 0.1248 \\
\hline $\mathbf{6 4}$ & 0.1236 & 0.325 & 0.325 & 0.1174 \\
\hline $\begin{array}{c}\text { joint } \\
\text { no }\end{array}$ & $\begin{array}{c}\text { THMR. } \\
\text { HNE }\end{array}$ & $\begin{array}{c}\text { THMR. } \\
\text { HNN }\end{array}$ & $\begin{array}{c}\text { TVUR. } \\
\text { HNE }\end{array}$ & $\begin{array}{c}\text { TVUR. } \\
\text { HNN }\end{array}$ \\
\hline $\mathbf{2 2 1}$ & 0.2006 & 0.2154 & 0.3451 & 0.4223 \\
\hline $\mathbf{1 2 4}$ & 0.1878 & 0.1932 & 0.3106 & 0.3562 \\
\hline $\mathbf{1 5 8}$ & 0.0646 & 0.0682 & 0.1099 & 0.1291 \\
\hline $\mathbf{6 4}$ & 0.05814 & 0.062 & 0.09669 & 0.1104 \\
\hline
\end{tabular}

building: an energy based approach". J.Indian Soc. Strut .Eng. 16(4), 13-24 (2014).

[4] C.Rajaram, "A study on pounding between Adjacent Buildings", MS Research Thesis, Civil Engg. Dept., International Institute of Information Technology Hyderabad, India (2011).

[5] Indian Meteorological Department, IMD, New Delhi.

[6] Pankaj Agarwal and Manish Shrikhande,"Earthquake Resistant Design of Structures(2006)".

[7] Shashikant K. Duggal,"Earthquake Resistant Design of Structures,second edition(2013)"

Table 6: Displacement at different ground motions

\begin{tabular}{|c|c|c|c|c|}
\hline \multicolumn{5}{|c|}{ Acceleration in m/sec } \\
\hline $\begin{array}{c}\text { joint } \\
\text { no }\end{array}$ & $\begin{array}{c}\text { KTPR } \\
\text {.HNN }\end{array}$ & $\begin{array}{c}\text { KTPR. } \\
\text { HNE }\end{array}$ & $\begin{array}{c}\text { PTNR. } \\
\text { HNN }\end{array}$ & $\begin{array}{c}\text { PTNR } \\
\text {.HNE }\end{array}$ \\
\hline $\mathbf{2 2 1}$ & 4945 & 4050 & 2146 & 2593 \\
\hline $\mathbf{1 2 4}$ & 593.9 & 1006 & 625.4 & 750.5 \\
\hline $\mathbf{1 5 8}$ & 1594 & 2362 & 497.6 & 580.2 \\
\hline $\mathbf{6 4}$ & 398.2 & 711.6 & 252.6 & 266.5 \\
\hline $\begin{array}{c}\text { joint } \\
\text { no }\end{array}$ & $\begin{array}{c}\text { THMR. } \\
\text { HNE }\end{array}$ & $\begin{array}{c}\text { THMR. } \\
\text { HNN }\end{array}$ & $\begin{array}{c}\text { TVUR. } \\
\text { HNE }\end{array}$ & $\begin{array}{c}\text { TVUR. } \\
\text { HNN }\end{array}$ \\
\hline $\mathbf{2 2 1}$ & 1369 & 1328 & 2203 & 3991 \\
\hline $\mathbf{1 2 4}$ & 251.1 & 228 & 243.7 & 322.5 \\
\hline $\mathbf{1 5 8}$ & 349.3 & 42.69 & 88.47 & 895.5 \\
\hline $\mathbf{6 4}$ & 116.6 & 103.1 & 228.6 & 338.1 \\
\hline
\end{tabular}

Table 7: Acceleration at different ground motions

\section{Conclusion}

- It is here by observed from the study maximum pounding forces increases as the period of structure increases

- Collision effect is more when separation distance is less

- At KPNR.HNE station, maximum displacement of building is observedPounding effect is maximum at top floors than at lower storeys

\section{REFERENCES}

[1] A.K.Chopra, "Dynamics of structures" (Pearson Education, Upper saddle River, 2001).

[2] Bureau of Indian standards IS 1893 (part 1):2007 (draft), "criteria for earthquake resistant design of structures", part-1 general provisions and buildings , bureau of Indian standards New Delhi, India (2007).

[3] C.Rajaram, R.K.Pradeep, A.P. singh, M.Kapil, B.K.Rastogi, "seismic damage estimation for port 